\title{
XBeach Process-Based Modelling of Coastal Morphological Features Near Breakwater
}

\author{
Mohd Shahrizal Ab Razak ${ }^{1, *}$, and Nur Arriffah Zaimah Mohd Nor ${ }^{1}$ \\ ${ }^{1}$ Department of Civil Engineering, Faculty of Engineering, Universiti Putra Malaysia 43400 Serdang Selangor, Malaysia
}

\begin{abstract}
An effective role of a detached breakwater as a coastal protection structure leads to morphological evolutions of tombolo. This paper presents the application of process based model of XBeach to investigate the morphological tombolo evolution using the model domain from the previous case study. Sensitivity analysis with optimum model parameters such as facua 0.1 , Chezy coefficient 60 , directional energy distribution, dtheta 10 and morfac 100 is conducted and the model results are compared to the empirical models. At 50 and 75 days simulation time, XBeach model results for breakwater at distance $120 \mathrm{~m}, 150 \mathrm{~m}, 200 \mathrm{~m}$ and $300 \mathrm{~m}$ offshore forms tombolo and salient at a distance of $500 \mathrm{~m}$ from the shoreline. Numerical investigation of tombolo through XBeach model has given us an understanding on the morphological effects of breakwater offshore distance towards evolution of coastal features like tombolo and salient.
\end{abstract}

\section{Introduction}

Detached breakwaters or also called as offshore breakwaters is a coastal protection structures which are built parallel to the shore [1]. Offshore breakwater plays an important role in blocking incoming wave energy thus creating a sheltered area as the wave energy is diminished. Offshore breakwaters are often used worldwide for four engineering purposes; (i) to shelter water bodies from waves, (ii) to protect beaches against erosion, (iii) to prevent silting of harbour entrances and (iv) to facilitate shore accretion for reclamation. Morphological changes occur in the stretch of the coastline with the construction of coastal structures [2]. Detached breakwater causes the coastline is subjected to less erosion as compared to other coastal structures since it does not block littoral drift completely and allows passage of drift material. The presence of coastal structure like detached breakwater has effect like trapping sand on the updrift side of the structure which takes sand out of the sediment budget thus causing shore erosion along the adjacent shorelines. It also blocks the incoming wave energy and creates a sheltered region, where the wave energy is diminished. The reduction of wave energy at the lee side of breakwater leads to the decreased of the sediment transport capacity and the sediment deposited eventually formed a salient or tombolo.

Tombolo is a narrow piece of land such as bar or spit that is attached to an island. It appears to be a small island that has not fully separated from the mainland. A tombolo is generally formed by the actions of wave diffraction and refraction. As wave energy diminished towards the coastline, waves are moving at a slower pace around the island. As the water moves slowly, it picks up sediment along the way. This sediment continues to build up until it creates sandbar which connects the island to the beach. For various times, beach response towards the development of detached breakwater as coastal protection measures do cause significant impacts that are not expected to occur due to improper planning prior to the design and placement of these structures. Consequently, it leads to excessive erosion and/or deposition of sediment as what has been occurring at Tok Jembal, a beach located on the east coast of Peninsular Malaysia. After years of critical coastal erosion, the bay becomes further unstable and causes endanger towards the public.

This paper is significant in the exploration of the coastal structure effects on the morphological process of tombolo evolution and the shoreline planform stability through an open source software called XBeach in twodimensional mode. The development of tombolo is quantitatively compared to the empirical models from previous researchers including [3] and [4].

\footnotetext{
*Corresponding author: ar_shahrizal@upm.edu.my
} 


\section{Empirical models of morphological effects of breakwater}

A conceptual model of shoreline is proposed by [3] in response to the data obtained from several projects of the United States, qualitatively there are five morphological responses to the breakwater system as shown in Figure 1.

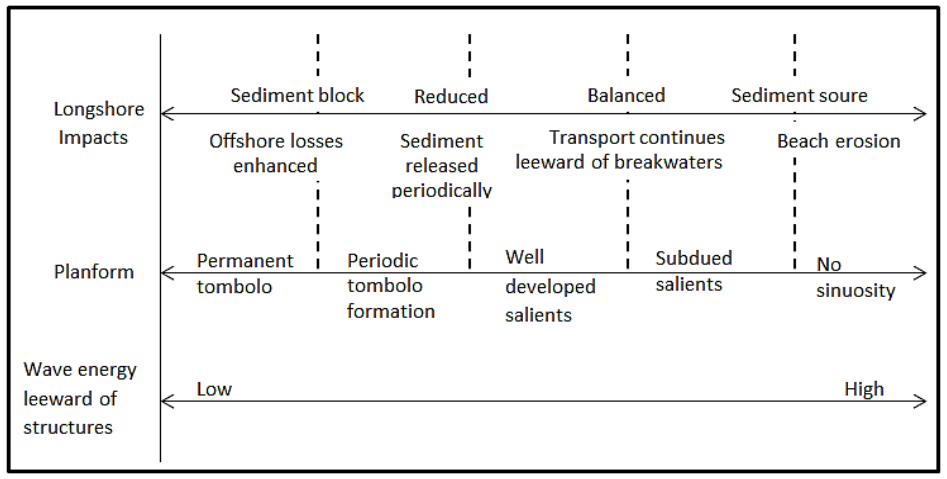

Fig. 1. Conceptual model depicting responses to detached breakwater. [3]

In Figure 1, permanent tombolo is a condition where very little wave energy reach the shoreline and the protected beach is stable with little transport of sediments along the shore. Littoral transport maybe displaced into deeper water, seaward of the breakwater. Periodic tombolo is a condition where there is variability in the wave energy reaching the lee of each individual segments of breakwater where one or more segments are periodically backed by tombolo. It may be unstable or stable through time, or the planform may vary through the project length. During high wave energy, severation of tombolo results in the formation of salient, while during low wave energy periods of sediment accretes and tombolo returns. Well-developed salient is a condition when there is higher wave energy reaches the lee of the breakwater and considered as a state of balanced sediment budget. It is not apparent until certain time passed for the shore to stabilize relative to the breakwater configuration. Subdued salient is a condition where the shoreline may periodically store and release sediment. The uniformity of the beach planform is not assured and there will be periods of increased loss and gain on the quantity of materials remain at the shoreline through time. No sinuosity is a condition where high wave energy approaches the beach, including the are directly behind the breakwater segments, thus beach fill may actually serve as a source of material for downdrift beaches.

The classification of the model is based on the degree of protection towards the coastline in terms of the relationship of the ratios of breakwater length to gap width $L B / G B$ and the breakwater distance from the shoreline to the average water depth at the breakwater $X B / d s$. When these data are plotted, it basically indicates the breakwater length, LB to the breakwater distance from the shoreline, $X B$ to define the beach response index, Is as Equation 1:

$$
I s=\exp [1.72-0.41(\mathrm{LB} / \mathrm{XB})]
$$

The values of Is basically aid in determining the categories of the shoreline response. This is however limited to basically based on breakwater-induced morphology that vary with the presence of tide/season and ignores any effects of variable gap width between breakwater. Further from that, [5] enhanced their research by specifying the following values of $I s$ :

$$
\begin{aligned}
& I s=0-1 \text { (permanent tombolo) } \\
& I S=1-2 \text { (periodic tombolo) } \\
& I S=2-3 \text { (well-developed salient) } \\
& I S=3-4 \text { (subdued salient) } \\
& I S=4-5 \text { (no sinuosity) }
\end{aligned}
$$

A limiting condition for a tombolo or salient formation in the function of $L_{B} / X_{B}$ versus $X_{B} / L$; where $L_{B}$ is the breakwater length, $X_{B}$ is the offshore distance of breakwater and $L$ is the wave length proposed by [6] is better presented as shown in Figure 2: 


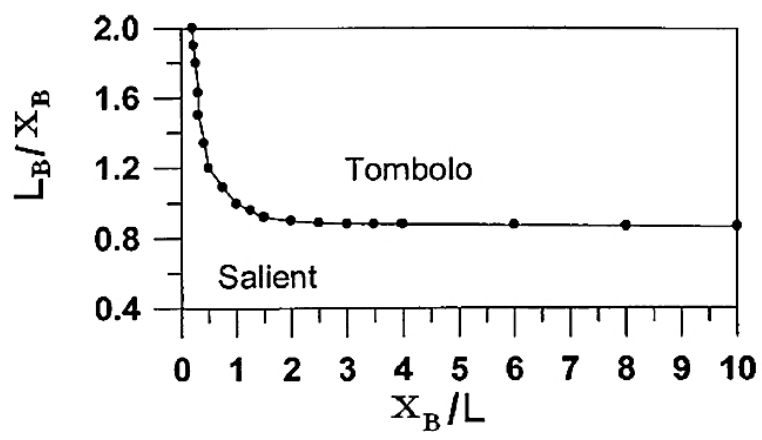

Fig. 2. Limiting condition of tombolo or salient formation by [6].

Based on [1], tombolo formation is influenced by the ratio of two parameters, breakwater length, $L_{B}$ to breakwater offshore distance, $Y_{B}$ where tombolo forms when $L_{B} / X_{B} \geq 1$. [7] also found that when the ratio of salient apex position, $X$ to breakwater length, $B$ is equal to 0 , this implies the formation of tombolo when the ratio of offshore distance, $S$ to the length of breakwater, $B$ is 0.2 as in Figure 3 .

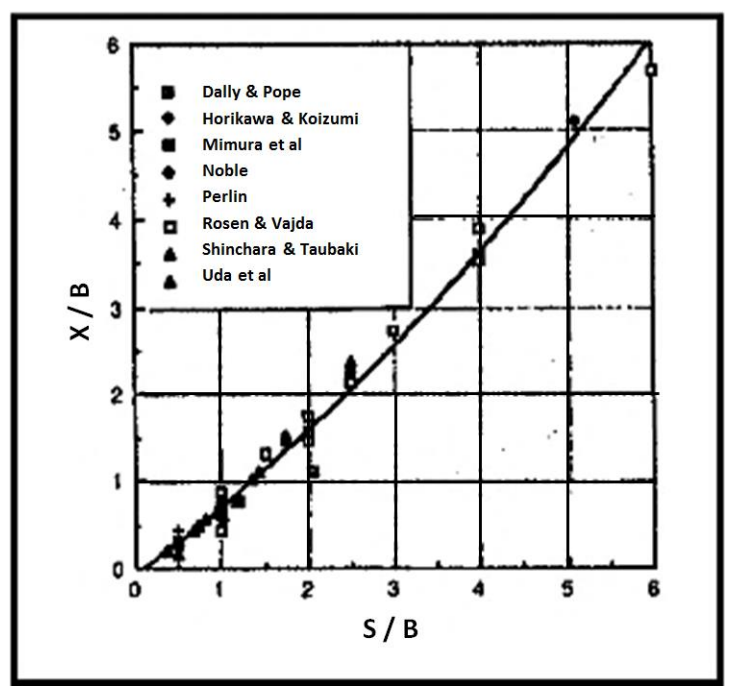

Fig. 3. Graph plot of distance breakwater to salient tip to breakwater length $(\mathrm{X} / \mathrm{B})$ versus the ratio of distance to initial shoreline to breakwater length $(\mathrm{S} / \mathrm{B})$. [7]

Besides, in order to have an effective geometric design of breakwater, there is a certain limit of detached breakwater distance relative to their lengths yielding incipient shore response. According to [8], the ratio of detached breakwater length $(L B)$ to its distance from the original shoreline $(Y B)$ is the main controlling components for coast morphology of breakwaters. The total volume of sand accumulation at the lee side of the breakwater is lower when the ratio of $(L B / Y B)$ is higher. Proposed by [9], the critical value for $(L B / Y B)$ ratio is between 3 to 6 according to their studies at California while [8] stated that accretion is very small or does not occur at all if the $(L B / Y B)$ ratio is equal or greater than 2 . There are various relationship range for the development of tombolo respective to the research which has been done. All the empirical relationships of the tombolo evolution are compiled into Table 1.

Table 1. Summary of tombolo evolution based on empirical relationships

\begin{tabular}{|c|c|}
\hline References & Relationship \\
\hline Gourlay (1981) & $\left(\mathrm{L}_{\mathrm{B}} / \mathrm{Y}_{\mathrm{B}}\right) \geq 0.67$ to 1.0 \\
\hline SPM (1984) & $\left(\mathrm{L}_{\mathrm{B}} / \mathrm{Y}_{\mathrm{B}}\right)>2.0$ \\
\hline Bishop (1982) & $\left(\mathrm{L}_{\mathrm{B}} / \mathrm{Y}_{\mathrm{B}}\right) \geq 1.0$ \\
\hline Noda (1984) & $\left(\mathrm{L}_{\mathrm{B}} / \mathrm{Y}_{\mathrm{B}}\right)=0.56$ \\
\hline Harris and Herbich $(1986)$ & $\left(\mathrm{L}_{\mathrm{B}} / \mathrm{Y}_{\mathrm{B}}\right)>1.0$ \\
\hline
\end{tabular}




\section{XBeach model description}

In this paper, only main description of XBeach is discussed. The model consists of formulations for short wave envelope propagation, non-linear shallow water equations, sediment transport and morphology bed update. The model calculates the radiation shear stresses that are included in the non-linear shallow water equation incorporating the effect of infragravity waves. Similar to other process-based model of coastal, the wave model takes into account the wave propagation processes such as shoaling, refraction and breaking processes. The infragavity waves are applied when the instationary wave is activated. For the purpose of simulation used in paper, only stationary wave module is used. The non-linear shallow water equation is incorporated in the model to compute the depth-averaged current velocity. The sediment transport formulation is based on the depth-integrated advection-diffusion equation. This means sediment will be transported or deposited based on the mismatch between the actual sediment concentration and equilibrium sediment concentration. If the actual sediment concentration is less than equilibrium sediment concentration, sediment will be picked up from the bottom bed. Otherwise, the sediment will be deposited. The sea bed is updated based on the gradient in sediment transport formulation. The formulation of avalanching and slumping of material is accounted in the model to simulate the changes of bed near the water line. Morphological scale factor is introduced to speed-up the computational time while preserving the accuracy of the morphological bed changes. Detailed model description and formulations of XBeach can be found in [10]. The selection of XBeach in simulating morphological processes against other existing coastal area models such as Delft3D, Mike, TELEMAC and others is due to several reasons. First, XBeach model is an open source programme, which means licence is not required. Source code of the model can be downloaded freely from the XBeach planform website. Second, model usage is simple and straight forward despite no user interface. It is applicable for a small-scale model covering few kilometres longshore and cross-shore directions. Thus, limiting the scope of study interest. Third, the stationary wave solver is stable and easy to be applied and finally, the model running is stable. The other advantages of XBeach are (i) the model does not require to have an additional domain grid for wave simulation. The same grid is used for both flow and wave computation. (ii) The simple algorithm for the implementation of stationary wave is programmed in the model and it is stable.

\section{Modelling approach}

A case study of [1] is taken as a reference case study for the research modelling. By referencing the model domain from the case study, this study employs the simulations of XBeach application in 2D mode according to the preferred model setup. The bed profile for the model setup has an initial slope of 1:50 and the profile shape was linear for all varying offshore distances from breakwater to shoreline following [1]. An equidistant grid size of $10 \mathrm{~m}$ in $\mathrm{x}$-direction and $\mathrm{y}$ direction is used to cover the whole domain area. Figure 4 shows the two-dimensional view of contour patches and the cross-shore bed profile that is used in all simulations performed in the study.
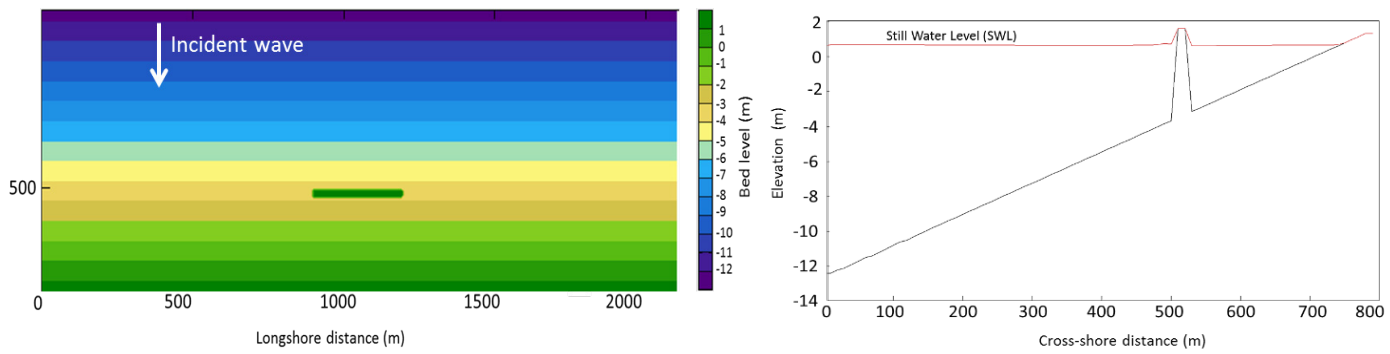

Fig. 4. Plan view (left) and schematized cross-shore bed level (right) of model bathymetry setting.

\subsection{Model scenarios}

Model test case for the study includes a single detached breakwater with a domain area of $2100 \mathrm{~m} \mathrm{by} 790 \mathrm{~m}$. The breakwater is subjected to stationary waves and the direction of the incident waves is perpendicular to the breakwater and the shoreline. Breakwater length, width and height are fixed at $300 \mathrm{~m}, 20 \mathrm{~m}$ and $1.61 \mathrm{~m}$. The value of $T p, H_{r m s}, H_{s}$, $\theta, D_{50}, D_{90}$ are $8.0 \mathrm{~s}, 2.0 \mathrm{~m}, 2.83 \mathrm{~m}, 270^{\circ}, 250 \mu \mathrm{m}$ and $350 \mu \mathrm{m}$, respectively. The breakwater crest level above (CWL) is set at $1 \mathrm{~m}$ and still water level (SWL) at $0.61 \mathrm{~m}$. Set at 50 and 75 days of simulation time, XBeach model is setup to run according to the scenarios as listed in Table 2. 
Table 2. Model scenarios

\begin{tabular}{|c|c|c|c|c|c|c|}
\hline $\begin{array}{c}\text { Case } \\
\text { scenarios }\end{array}$ & $\begin{array}{c}\text { Offshore } \\
\text { distance of } \\
\text { breakwater }\end{array}$ & $\begin{array}{c}\text { Model } \\
\text { simulation } \\
\text { time (days) }\end{array}$ & Effect of facua & $\begin{array}{c}\text { Effect of } \\
\text { Chezy }\end{array}$ & $\begin{array}{c}\text { Effect of } \\
\text { directional } \\
\text { energy } \\
\text { distribution } \\
(\text { dtheta })\end{array}$ & $\begin{array}{c}\text { Effect of } \\
\text { morfac }\end{array}$ \\
\hline I & $120 \mathrm{~m}$ & 50 & $\begin{array}{c}0.1,0.2,0.3,0.4,0.5, \\
0.6,0.7,0.8,0.9,1.0\end{array}$ & $\begin{array}{c}20,40,60 \\
, 80,100\end{array}$ & $5,10,15,20$ & 10,50, \\
\hline II & $120 \mathrm{~m}$ & 50 & 0.1 & 60 & 10 & 100 \\
\hline III & $150 \mathrm{~m}$ & 50 & 0.1 & 60 & 10 & 100 \\
\hline IV & $200 \mathrm{~m}$ & 50 & 0.1 & 60 & 10 & 100 \\
\hline V & $300 \mathrm{~m}$ & 50 & 0.1 & 60 & 10 & 100 \\
\hline VI & $500 \mathrm{~m}$ & 75 & 0.1 & 60 & 10 & 100 \\
\hline
\end{tabular}

Scenario I is the sensitivity analysis on the calibrations of the XBeach parameter settings that includes facua (an indicator to calibrate the wave skewness and asymmetry), Chezy (surface roughness), directional energy distribution, dtheta (directional spreading of wave energy) as well as morfac (speeds up morphological time scale relative to hydrodynamic timescale). The rest of the scenarios are the XBeach model simulations done with varying offshore distances of breakwater at $120 \mathrm{~m}, 150 \mathrm{~m}, 200 \mathrm{~m}$ at $2100 \mathrm{~m}$ by $790 \mathrm{~m}$. However, for breakwater at distance $300 \mathrm{~m}$ and $500 \mathrm{~m}$ offshore, the model domain area is extended cross-shore at $990 \mathrm{~m}$. By having the extension of the domain area cross-shore, this allows an enough space for the propagation of the incoming waves simulated by XBeach program to be dissipated passing through the detached breakwaters.

\section{Model results}

Scenario I presents the step by step process of the tombolo evolution when the breakwater is situated at $120 \mathrm{~m}$ offshore distance from the shoreline as shown in Figure 5 shows the height development of tombolo along the process. Simulations of tombolo development includes $\mathrm{t}=0,5,10,20,30$ and 50 days. $\mathrm{T}=0$ day shows the condition before any morphological process of tombolo started while at $\mathrm{T}=5$ and 10 days, morphological process of tombolo starts to take place through the process of wave refraction and diffraction within the extremities of the breakwater thus forming initial sediment development of salient. By the dissipation of the wave energy due to the presence of the breakwater, waves start to move at a slower pace around the shoreline enhancing current circulation behind the breakwater and picks up sediment along the way. This sediment then continues to build up as seen at $\mathrm{t}=20$ days and $\mathrm{t}=30$ days until it creates a sandbar that fully connects the shoreline to the breakwater, forming a fully developed tombolo at $\mathrm{t}=50$ days.

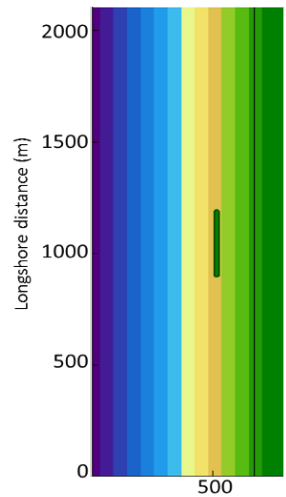

(i)

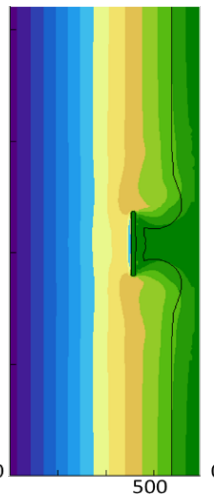

(ii)

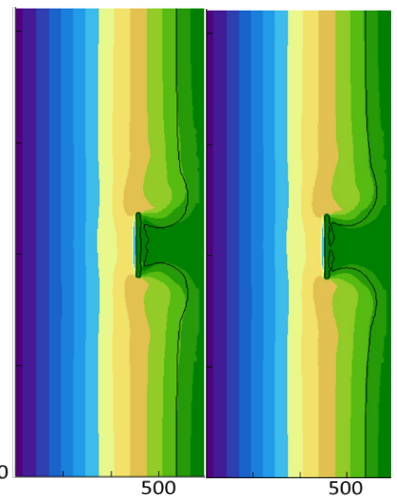

(iii)

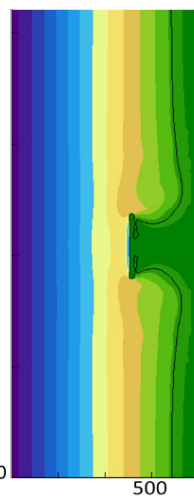

(v)

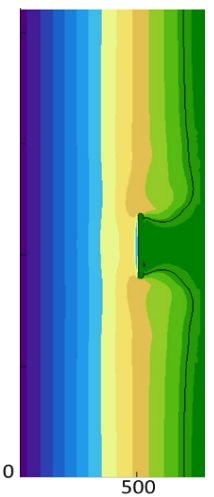

(vi)

Cross-shore distance $(\mathrm{m})$

Cross-shore distance $(\mathrm{m})$

Fig. 5. Tombolo development process at (i) $t=0$ day, (ii) $t=5$ days, (iii) $t=10$ days, (iv) $t=20$ days, (v) $t=30$ days and (vi) $t=50$ days

Model scenario II, III, IV and V forms tombolo evolution while scenario VI forms into salient. Dissipation of wave energy as it hits the detached breakwater causes accretion at the sheltered zone between the breakwater and the shoreline. Most of the sediment comes from the breakwater extremities when the breakwater is closer to the shoreline and the zone covered by the tombolo is filled with sediment due to the effect of swash or wind effect. Small eddies are formed at the lee side of the breakwater due to the variation of wave height which causes the movement of sediment to stir up by wave action that eventually leads to big scour holes generation. This movement forms a swirling current 
circulation behind the breakwater and picks up sediment along the way thus forming tombolo when breakwater is situated at $120 \mathrm{~m}, 150 \mathrm{~m}, 200 \mathrm{~m}$ and $300 \mathrm{~m}$ of scenario II, III, IV and V as shown in Figure 6.

In contrast, as the breakwater distance to the shoreline increases, the morphological changes of the sediment accumulation also changes. Waves entering the sheltered area behind the breakwater also increases the effect and amount of sediment transported. Various flows of waves are formed and causing sediment from the nearshore zone to be trapped into salient as shown in Figure 7, when the breakwater is situated at $500 \mathrm{~m}$ distance offshore of scenario VI.
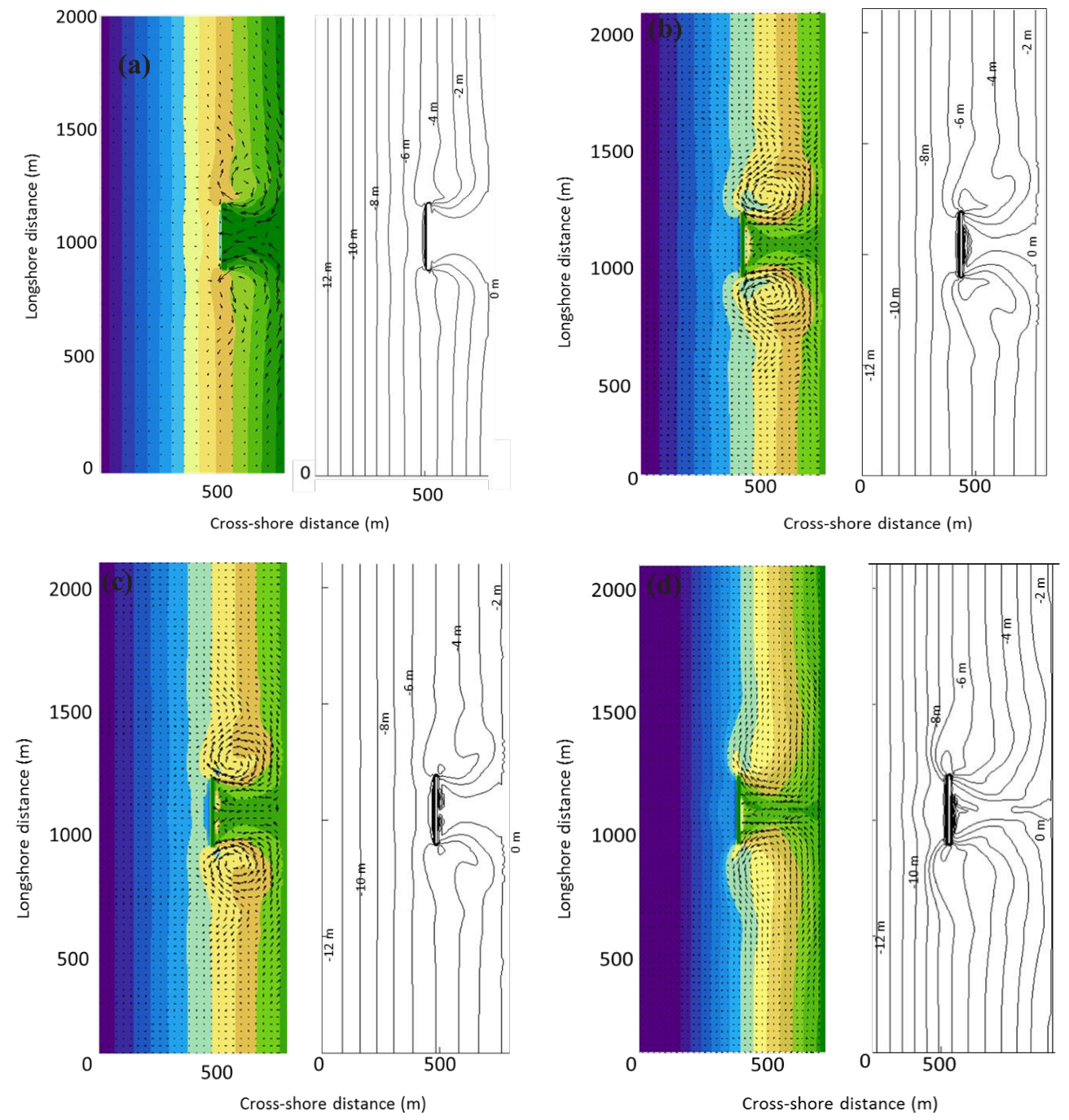

Fig. 7. Tombolo development at the end of simulation for (a) scenario II (XB $120 \mathrm{~m}$ ), (b) scenario III (X $150 \mathrm{~m}$ ), (c) scenario IV (XB $200 \mathrm{~m})$, (d) scenario V ( $\left.\mathrm{X}_{\mathrm{B}} 300 \mathrm{~m}\right)$ 


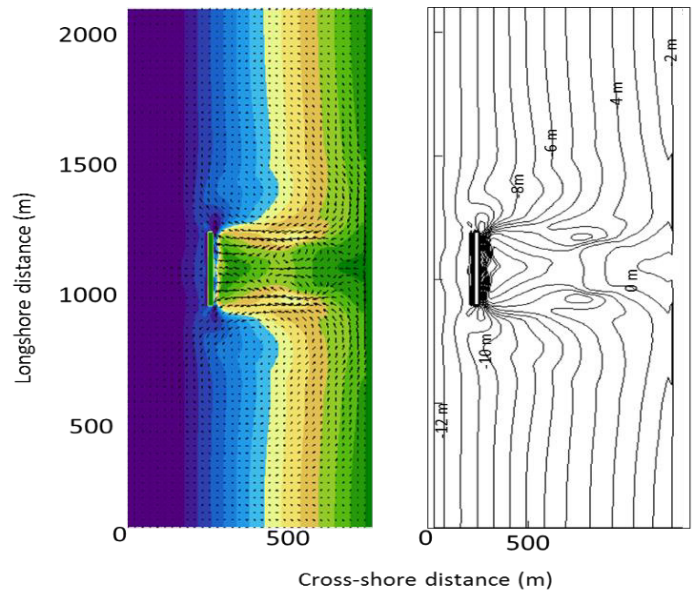

Fig. 8. Tombolo development at the end of simulation for scenario VI $\left(\mathrm{X}_{\mathrm{B}}=500 \mathrm{~m}\right)$

A tombolo forms when the length of the breakwater is longer than 0.8 times the distance between the shore and the breakwater while at 0.8 times shorter, salient will be developed. The overall results of the XBeach simulation for all scenarios are summarised in Table 3.

Table 3. XBeach model results summary and categorisation

\begin{tabular}{|c|c|c|c|c|}
\hline Scenario & $\begin{array}{c}\text { Offshore distance of } \\
\text { breakwater }(\mathrm{m})\end{array}$ & $\begin{array}{c}\text { Simulation time } \\
\text { (days) }\end{array}$ & $\mathrm{L}_{\mathrm{B}} / \mathrm{Y}_{\mathrm{B}}$ & $\begin{array}{c}\text { Beach category } \\
\text { simulated by XBeach }\end{array}$ \\
\hline II & 120 & 50 & 2.5 & Tombolo \\
\hline III & 150 & 50 & 2.0 & Tombolo \\
\hline IV & 200 & 50 & 1.5 & Tombolo \\
\hline V & 300 & 50 & 1.0 & Nearly tombolo \\
\hline VI & 500 & 75 & 0.6 & Salient \\
\hline
\end{tabular}

\subsection{Comparison between Model Results and Empirical Relationships}

The XBeach model results satisfies the empirical relationships introduced by [11] and [12] with ratio LB/YB more or equal than 2 and 1 respectively. However, it does not comply to the empirical relationship proposed by [13], [14] and [15]. This comparison is summarised in Table 4 accordingly.

Table 4. Ratio of breakwater length to breakwater distance from shoreline, LB/YB of model results comparison to the tombolo evolution empirical relationships

\begin{tabular}{|c|c|c|c|c|c|}
\hline References & $\begin{array}{c}\text { Relationship } \\
\text { (tombolo formation) }\end{array}$ & $120 \mathrm{~m}$ & $150 \mathrm{~m}$ & $200 \mathrm{~m}$ & $300 \mathrm{~m}$ \\
\hline Gourlay (1981) & $\left(\mathrm{L}_{\mathrm{B}} / \mathrm{Y}_{\mathrm{B}}\right) \geq 0.67$ to 1.0 & 2.5 & 2.0 & 1.5 & 1.0 \\
\hline SPM (1984) & $\left(\mathrm{L}_{\mathrm{B}} / \mathrm{Y}_{\mathrm{B}}\right)>2.0$ & 2.5 & 2.0 & 1.5 & 1.0 \\
\hline Bishop (1982) & $\left(\mathrm{L}_{\mathrm{B}} / \mathrm{Y}_{\mathrm{B}}\right) \geq 1.0$ & 2.5 & 2.0 & 1.5 & 1.0 \\
\hline Noda (1984) & $\left(\mathrm{L}_{\mathrm{B}} / \mathrm{Y}_{\mathrm{B}}\right)=0.56$ & 2.5 & 2.0 & 1.5 & 1.0 \\
\hline $\begin{array}{c}\text { Harris and Herbich } \\
(1986)\end{array}$ & $\left(\mathrm{L}_{\mathrm{B}} / \mathrm{Y}_{\mathrm{B}}\right)>1.0$ & 2.5 & 2.0 & 1.5 & 1.0 \\
\hline
\end{tabular}

The formation of tombolo and salient with respect to varying offshore distances of breakwater nevertheless fall perfectly to the limiting conditions of [6]. From Figure 9, it can be observed that scenario II, III, IV and V falls above the proposed limiting line of [6] which is categorised as tombolo while scenario VI falls below the proposed line and categorised as salient. These empirical results are matched perfectly to the model results captured by XBeach model. 


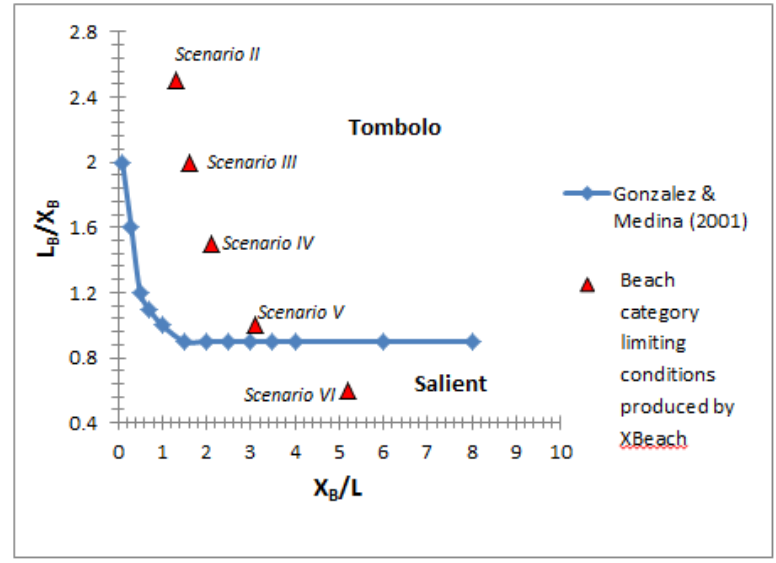

Fig. 9. Beach category for all scenarios according to [6] and XBeach model results based on different scenario cases.

Although the empirical relationship introduced by [3] that is supported by [5] provides a wide range of morphological changes categories, the variation in the model results with the conceptual model introduced by them are significantly different. Instead of forming tombolo at breakwater $120 \mathrm{~m}, 150 \mathrm{~m}, 200 \mathrm{~m}$ and $300 \mathrm{~m}$ offshore distance, conceptual model of [3] claimed it to be salient. It may be use as a rough guide for shoreline evolution, yet it does not appear to be complying with the model conditions of this study. Although the wave condition for this study is considered as hypothetical case (normal incident wave) that is different from the real wave conditions, yet the model results for this study are almost similar to the literature results of the reference case study [1]. This model result is also supported by the statement from [16] where the closer the distance of the breakwater to the offshore, the greater the tendency of the formation of tombolo.

\section{Conclusion}

The analysis of a single detached breakwater in this paper is seen as the first step in the development of a reliable modelling tool of XBeach that can be used to predict the morphological response behind complex arrays of shore protection structures. With the application of the XBeach parameters of facua, Chezy coefficient, dtheta and morfac values on the model domain of the study, it is possible to conclude that the shoreline changes behind a detached breakwater is influenced by the offshore distance of the breakwater as well as the wave flows approaching the shoreline. Within the varying offshore distance condition of the breakwater, the shoreline produces different morphological evolutions including tombolo and salient. It can be concluded that this research is only considering the numerical investigation of morphological effects towards the shoreline response in formation of tombolo near coastal structure of breakwater.

The XBeach model results shows that the downdrift affects the most frequent erosion on the shoreline. In general, downdrift in the tombolo formation certainly causes erosion within any values of parameters, while the downdrift in salient formation is likely to cause erosion, however seldom, it is accreted. It can also be observed that the shore at the updrift is impacted by the detached breakwater causing it to fluctuate from accretion to erosion depending on the magnitude and the capabilities of the breakwater in dissipating the wave energy within their location from the shoreline. Siltation of tombolo and salient, both faces a loss of sediment and a growth of sediment. The updrift of the tombolo formation is less frequently eroded compared to salient.

In conclusion, a detached breakwater does has a significant effect on wave energy dissipation and development of tombolo along the shoreline depending on the offshore distance of the breakwater. XBeach, with its default value of parameter settings is one of the most efficient program in simulating the shoreline pattern and visualise the morphological process of tombolo evolution.

The authors would like to acknowledge the efforts made by the postgraduate student on the modelling works. Results presented are part of the dissertation thesis.

\section{References}

1. S.M.A Ahmed, 2D and 1D Numerical Model Simulations For The Effect of a Single Detached Breakwater on the Shore. Master Thesis, Delft University of Technology, 1-241 (1997)

2. A.M. Vaidya, K. K. Santosh, and M.D. Kudale, Shoreline Response to Coastal Structures. International Conference 0n Water Resources, Coastal and Ocean Engineering (ICWRCOE 2015). Aquatic Procedia 4, 333 - 340. (2015) 
3. J. Pope, and J.L. Dean, Development of Design Criteria for Segmented Breakwaters. Coastal Engineering, Chap $158,2144-2158(1986)$

4. M. Gonzalez, and R. Medina, Equilibrium Shoreline Response Behind a Single Offshore Breakwater. Proceedings Coastal Sediment, 1, 933-942 (1999)

5. J.P. Ahrens, J. Cox, Design and performance of reef breakwaters. Journal of Coastal Research, 7, 61-75 (1990).

6. M. Gonzalez, R. Medina, On The Application of Static Equilibrium Bay Formulations to Natural and Man-Made Beaches. Coastal Engineering, 43, 209-225. (2000).

7. J.R.C. Hsu, C. Evans, Parabolic Bay Shapes and Applications. Proceedings of Institutions of Civil Engineers, London, England, 87, 2, 556-570 (1989)

8. Y. Nir, Offshore Artificial Structures and Their Influence on the Israel and Sinai Mediterranean Beaches. Proceedings 19th Coastal Engineering Conference, ASCE, 1837-1856 (1982)

9. L.D. Inman, and J.D. Frautschy, Littoral Processes and the Development of Shorelines, Proceedings Coastal Engineering, 511-536 (1965)

10. D. Roelvink, A. Reniers, A.V Dongeren, J.V. Thiel de Vries, R. McCall, J. Lescinski, Modelling Storm Impacts on Beaches, Dunes and Barrier Islands. Coastal Engineering, 56:1133-1152. (2009).

11. M.R. Gourlay, Beach Process in the Vicinity of Offshore Breakwaters. Proceedings of 5th Australian Conference on Coastal and Ocean Engineering (ACCOE 1981), 129-134. Australia (1981).

12. C.T. Bishop, A Review of Shore Protection by Headland Control. National Water Research Institute, Canada Center for Inland Waters (1982)

13. SPM. Shore Protection Manual 4th Ed. Washington, D.C.: USAE-WES Coast. Engrg. Res. Ctr., U.S. Govt. Printing Ofc. (1984)

14. H. Noda, Depositional Effects of Offshore Breakwater Due to Onshore-Offshore Sediment Movement. Proceedings 19th Coastal Engineering Conference, ASCE, 2009-2025 (1984)

15. M.M. Harris, J.B. Herbich, Effect of Breakwaters Spacing on Sand Entrapment. Proceedings IAHR-Symposium86 on Scale Effects in Modelling Sediment Transport Phenomena, Toronto, Canada (1986).

16. L.E. Brandon, Investigation of the Effects of Detached Breakwaters at Holly Beach and Grand Isle, Louisiana. Master Thesis, Louisiana State University, 1-117 (2002) 